\title{
Adult roles and the gender gap in political knowledge: a comparative study
}

\author{
Monica Ferrín ${ }^{a}$, Marta Fraile ${ }^{b, c}$ and Gema M. García-Albacete ${ }^{d}$ (D)

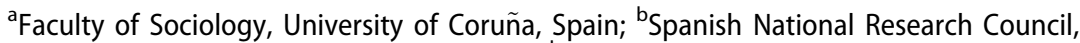 \\ Spain; ' $E$ European University Institute, Italy; ${ }^{d}$ Department of Social Sciences, \\ Universidad Carlos III de Madrid, Spain
}

\begin{abstract}
The unusual size and persistence of the gender gap in political knowledge is perplexing in comparison to other dimensions of politics. Building on situational explanations of political engagement, this article claims that women's and men's specific adult roles lead to an enlargement of the gender gap in knowledge. The present study analyses men and women's levels of political knowledge at different life stages by means of two unique datasets specifically collected to measure what people know about politics. Findings show that adult roles provide more opportunities for men to gain political knowledge than for women. Furthermore, the comparison of levels of political knowledge in two such dissimilar countries as Finland and Spain suggests that while gender equality policies are successful in tearing down some of the obstacles that hinder women's contact with the political world, they are still insufficient to completely bridge the gender gap in political knowledge during adulthood.
\end{abstract}

KEYWORDS Political knowledge; gender gap; adult roles; public opinion; Finland; Spain

The inclusion of women in politics has improved significantly during recent decades across Western democracies. Gender differences in electoral turnout, which is the most basic form of political participation, have vanished (Burns et al. 2001; at least in first-order elections Kostelka et al. 2019). Some of the so-called emerging forms of participation - such as political consumerism - also encourage women's political activity (Stolle and Micheletti 2013). However, an imbalance persists between women and men's political involvement, and one of the strongest examples of this is gender difference in political knowledge. Women's poorer knowledge of politics is one of the most persistent findings in nearly every Western democracy (Delli Carpini and Keeter 2005; Fraile and Gomez 
2017). Women systematically lack a resource that is fundamental to the formation of political opinions and processing of new information, as well as for decision-making about electoral choices (Delli Carpini and Keeter 1996; Kostelka et al. 2019); and which is also a determinant of other forms of political participation (Ondercin and Jones-White 2011).

Prior work on the gender gap in general political engagement has provided explanations mainly related to the differentiated positions of women and men in society (Schlozman et al. 1999), while recent research on the gender gap in political knowledge has focused on methodological concerns about how political knowledge is understood and measured. Women and men are indeed socialised into gender roles that define politics as a 'man's world'. In addition, women today still have lower levels of education, income and employment, all of which are important predictors of political engagement. When it comes to political knowledge specifically, most recent research suggests that the format and content of questions often used to measure political knowledge might be biased in favour of men's political interests (Dolan 2011; Ferrín et al. 2017; FortinRittbergger 2016; Stolle and Gidengil 2010).

In this article we combine these theories and argue that the relationship between adult roles and levels of political knowledge might contribute to explaining one of the most persistent inequalities in political engagement. A consistent finding in the extant literature is that the gender gap in political knowledge is greater among adults than among young people (Fraile 2014; Hahn 1998; Jennings 1996; Jennings and Niemi 1974) but, to the best of our knowledge, no study has examined in depth this remarkable finding. However, if the gender gap in knowledge is barely visible among adolescents and young adults, but clearly evident among adults, attention should be paid to the meaning of adulthood.

Building on situational explanations of political engagement, we contend that women's and men's specific adult roles lead to a widening of the gender gap in knowledge. The study of two very dissimilar cases Finland and Spain - with regard to gender differences in the social, political and economic spheres allows us to test whether the differences observed among adult statuses are independent of the context. The use of two unique datasets specifically designed to measure citizens' political knowledge allows us in addition to incorporate the most recent suggestions on how to measure such knowledge.

We find that adult roles, and particularly parenthood, are associated with different levels of knowledge between men and women both in Finland and Spain. Our findings suggest that gender equality policies help ameliorate the consequences of traditional private-sphere activities that keep women away from politics, especially during youth. Nonetheless the 
persistence of the gender gap in political knowledge might be driven by the fact that women still carry the burden of family responsibilities, even in countries with the highest levels of gender equality. We discuss the implications of these findings in the final section.

\section{Gender gap in political knowledge and adult roles}

A number of studies have shown that adult roles contribute to explaining gender differences in political participation and political attitudes (Banducci et al. 2016; Munch et al. 1997; Quaranta 2016; Quaranta and Dotti-Sani 2018; Stoker and Jennings 1995; Voorpostel and Coffé 2010). These studies find that individuals' statuses as parents or spouses have a differential effect on women's and men's political engagement and preferences. Banducci et al. (2016), for example, find that motherhood is more strongly associated with favouring government-supported childcare provision than fatherhood. Motherhood is also shown to be an obstacle to running for political office (Sapiro 1982) and as a depressor of some forms of political participation (García-Albacete 2014; Quaranta 2016; Quaranta and Dotti-Sani 2018). In this study we build on these findings and propose that gendered adult roles contribute to understanding the persistence of the gender gap in political knowledge.

The main argument in political behaviour research to explain changes in political involvement across the life-cycle is that adult roles bring individuals the experience and knowledge that make politics easier to understand and more meaningful (Strate et al. 1989). However, the scattered evidence available on this topic suggests that this process is different for women. Whilst starting off from very similar levels of political knowledge as children (Torney-Purta et al. 2001; Goetzmann 2017), ${ }^{1}$ women's knowledge lags behind that of men once they reach adulthood (Hahn 1998; Jennings 1996; Jennings and Niemi 1974). In the context of the US, Jennings (1996: 248) shows that over time women gain less political knowledge than men, which substantially increases the awareness gap between adult women and men (see also Jennings and Niemi 1981: 280-81). Fraile (2014) shows that the gender gap in knowledge about national and European politics is persistent across all European countries and that the size of the gap increases with age. What is it that comes with adult roles that slows down women's learning about politics compared to men's?

Adulthood brings new situations for women and men in their domestic life and, more broadly, in society (Welch 1977: 714-15), which might affect an individual's relationship to politics. Life course studies point to five demographic markers in the transition to adulthood: leaving the parental home; completing education; entering the labour market; living with 
a partner; and having the first child (Gauthier and Furstenberg 2002; Shanahan 2000: 627). Each step entails changes in resources, as well as preferences (Voorpostel and Coffé 2010: 2). Among the different statuses, previous research has pointed at family-related and occupational statuses as particularly relevant for political involvement given their relationship with two types of resources that might have an impact on levels of political engagement: networks and time.

As discussed above, little attention has been paid to variations in levels of political knowledge and adult roles, but research on political behaviour provides potential explanations. Entering the labour market and living with a partner, for instance, foster political participation due to an increase in networking opportunities and exposure to mobilisation agencies (Stoker and Jennings 1995; Verba et al. 1995). As exposure to heterogeneous networks and agencies increase, so will the political information that is available to individuals. A different life event, having a child, causes ambivalent effects on political involvement: on the one hand, parenthood increases social needs such as education or play facilities, which raises political awareness (Lane 1959: 218); but on the other hand it reduces available time and therefore the likelihood of engaging in networking (Gallagher and Gerstel 2001). Yet each of these adult statuses might have a different impact on women's and men's political knowledge in terms of the type and amount of resources they involve. Adult roles in fact reinforce the division of labour between women and men (Schlozman et al. 1999). This study now turns to look in more detail at these adult roles, specifically in paid employment, cohabitation and parenthood.

Regarding paid employment, since a working environment provides social networks and mobilisation agencies, and increases economic resources (Strate et al. 1989; Verba et al. 1995), we might expect that entering the labour market is generally associated with higher levels of political knowledge both for women and for men. However, given that, even today, it is more likely that women are employed in more part-time and low-level jobs than men (ILO 2015) - especially after childbirth (Eurostat $2016)^{2}$ - benefits related to paid employment might be higher for men than for women. From here we derive our first hypothesis (H1) which states that paid employment will have an overall positive association with levels of political knowledge, but the relationship will be stronger for men than for women.

Family-related statuses bring about greater gender differences. Regardless of whether they also work full-time outside the home, women tend to be more committed to child-rearing, and general family life (Batalova and Cohen 2002; Knudsen and Waerness 2008). Family 
responsibilities (as wives, mothers, carers and home-makers) often involve a double burden of work for women but not for men (Baxter et al. 2008, 2015), whose average contribution to housework and caring activities has actually been shown to decline after marriage (Sayer 2005). In terms of resources, due to the division of labour within the household, women have fewer opportunities to engage in networking and less time to dedicate to politics than men. Evidence shows that marriage significantly hinders women's political involvement while boosting men's, and that parenthood has a negative relationship with women's social networking and political participation; but not for men (García-Albacete 2014; Munch et al. 1997; Quaranta 2016; Quaranta and Dotti-Sani 2018). In light of previous evidence, we would expect that cohabitation (or marriage) and especially parenthood have a different association with levels of political knowledge for women and for men, as the amount (and type) of resources that comes with each of these statuses differs for each sex. More specifically, the positive relationship of living with a partner and political knowledge will be greater for men than for women (H2). Parenthood also implies a large amount of unpaid work required at home, and this limits the amount of time available to dedicate to politics. Since women tend to take the burden of responsibilities in relation to childcare, motherhood will have a negative relationship with women's level of political knowledge (H3).

Situational factors cannot be considered alone, however, since how gender roles are constructed depends on the context, both at household and country levels. In relation to the country level, gender equality policies might have an influence on how women and men view their roles as adults. Two elements are of particular relevance for our argument: how balanced the country's labour market is between women and men, and the amount of resources available to families - such as childcare, elderly care, etc. These types of resources account for structural factors that might impact on gender differences in political knowledge. First, a balanced labour market implies that both women and men benefit from networking and therefore have more resources at their disposal to be informed about politics. Second, family-friendly policies imply more resources (especially) for women (i.e. time), as they will not be carrying the whole burden of family care responsibilities. Considering all this, we would expect that there are no significant differences in the impact of adult roles on women and men in contexts that are gender-balanced and which provide more resources to women. On the contrary, contexts with high gender inequality would significantly differentiate the impact of adult roles between women and men: in these contexts, women are expected to be more disadvantaged than men (H4). 


\section{Two case studies: Finland and Spain}

In order to test whether the effect of transition to adulthood is dependent on the context, we study levels of political knowledge of women and men in Finland and Spain. The selection of our case studies is oriented both pragmatically and theoretically. From a pragmatic point of view, Finland and Spain have been chosen due to availability of data. In both countries, there exist unique data aimed at measuring citizens' levels of political knowledge, which is not restricted to classic standard measures. Considering the strong critiques that standard indicators of political knowledge are biased in favour of men's interests (e.g. Dolan 2011; Ferrín et al. 2018; Stolle and Gidengil 2010), this choice is not trivial (this point is explored in more detail below).

Comparison from a theoretical perspective is particularly relevant, as Finland and Spain are normally included in two different paradigms of adulthood transition and family formation. Whereas Finland is included in the maternalistic cluster, Spain is considered paternalistic (Mellens 1999). The former is defined by high levels of female participation in the labour market, and high levels of childcare facilities. In addition, in the maternalistic cluster 'female values' like cooperation are more likely to be emphasised, and there are low levels of conservatism, especially in relation to family formation (Mellens 1999: 34). In contrast, in the paternalistic cluster there is a prevalence of traditional family values, lack of female emancipation, scarce childcare facilities, high conservatism and low gender equality (Mellens 1999: 36).

Maternalistic and paternalistic clusters are closely linked to specific types of welfare states (Mayer 2001). Finland belongs to the social democratic welfare regime, which is oriented towards the individual, and allows individual's freedom of choice, independent of the family (EspingAndersen 1990; Hilson 2008). Spain aligns itself instead with other South European countries in what has been defined as a variant of the conservative welfare regime, which is highly oriented to the family and has a low level of provision by the state. As a consequence, there is a heavy reliance on the family to provide welfare to its members (Ferrera 1996). This all leads to different transition patterns in these two countries: the Finns are more inclined towards early independent/non-parental living arrangements and early non-traditional union formation, whereas Spaniards tend to delay all major transition events (Buchmann and Kriesi 2011: 492-3).

Although these models are not static and have evolved over time due to demographic changes, both countries still appear to be placed very differently in relation to the amount of resources that most directly influence women's situation in the household. For example, even today there are large differences in total expenditure in social policies per inhabitant of these two 
Table 1. Expenditure in social policies and family/children policies.

\begin{tabular}{|c|c|c|c|c|}
\hline & \multicolumn{2}{|c|}{$\begin{array}{l}\text { Total expenditure } \\
\text { social policies* }\end{array}$} & \multicolumn{2}{|c|}{ Family/children* } \\
\hline & 2008 & 2012 & 2008 & 2012 \\
\hline Finland & 8527.44 & 9398.36 & 959.10 & 1010.52 \\
\hline Spain & 4702.03 & 4852.16 & 290.60 & 258.62 \\
\hline
\end{tabular}

*Euros per inhabitant (constant prices 2005).

Source: Eurostat 2008, 2012.

countries, especially in relation to family and childcare. Finland spends four times more than Spain on family and childcare policies (see Table 1).

Finland also presents a higher level of gender equality than Spain in other domains such as labour, economy, education, politics and time use, according to the indexes of gender equality from the European Institute for Gender Equality (EIGE, see Figure 1). Inequalities in Spain are particularly large in the economic and power domains, which indicate that, compared to Finland, there is a low presence of women in high-level positions. In relation to politics, EIGE data indicate that Spain is amongst the most equal countries in Europe, although socialisation in democratic politics is relatively recent in Spain when compared to Finland. While women's involvement in politics started early in the twentieth century in Finland (considered a democracy since 1917), it was not until the constitutional process in Spain (1977) that women started to have visibility in politics. Even then a relatively long time-span was needed to increase women's participation as political leaders, as it started with a very small number of women $(5.8 \%)$ in the constitutional framing of the new democratic system (for the long-term impact of descriptive representation on the gender gap in knowledge see Dassonneville and McAllister 2018).

The large differences between Finland and Spain, in terms of gender equality and welfare regimes, do not imply that Finland should be considered a totally gender-equal country, as the average index falls short of the ideal $100 \%$ that would indicate perfect equality. Nonetheless, and considering $\mathrm{H} 4$, we expect that, although not identical, adult roles have a more similar impact on men's and women's levels of political knowledge in Finland than in Spain.

\section{Data}

To test our hypotheses we use data that were collected specifically to assess citizens' levels of political knowledge in Finland and Spain. In Finland, 'Knowledge of Politics in Society', a face-to-face representative survey $(n=1020)$, was conducted in 2008 (Elo and Rapeli 2010, 2014). In Spain, the face-to-face survey 'Knowledge of Social, Political and 


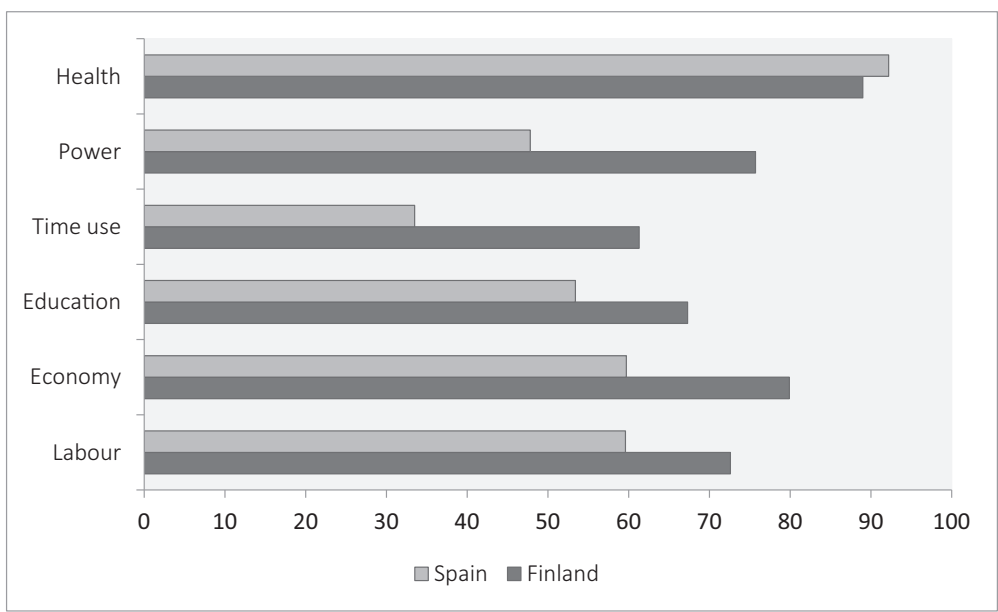

Figure 1. Gender equality in six domains in Finland and Spain.

Source: Gender Equality Index, EIGE.

Economic Issues' was conducted by the Centro de Investigaciones Sociológicas in 2012 (CIS 2973), on a representative sample of the Spanish population $(n=2962){ }^{3}$ Both surveys are unique in that they include a broad range of questions to measure political knowledge, which vary in content, format and difficulty (see Tables A1 and A2 in the online appendix). In this sense, the design of these questionnaires integrates a series of methodological features to overcome the critique that the gender gap in political knowledge could (at least in part) be an artefact of the format and content of the questions used in the surveys (e.g. Dolan 2011; Ferrín et al. 2017, 2018; Fortin-Rittbergger 2016; Mondak and Anderson 2004; Stolle and Gidengil 2010).

The ideal dataset to use here would consist of panel data including repeated measures for the same individuals across time to identify the impact of changes in the life-cycle on changes in political knowledge across time (through the estimation of fixed effects) and potential generational effects. Unfortunately, those kinds of datasets are scarce and completely unavailable for political knowledge. Notwithstanding this limitation, cross-sectional data is often used in the literature to address the relationship between political attitudes and adult roles (see for instance Banducci et al. 2016; García-Albacete 2014; Quaranta 2016; Quaranta and Dotti-Sani 2018).

Political knowledge is often conceptualised broadly as information and factual knowledge about the political system, its institutions and processes, leaders and players, domestic politics, foreign affairs and policies (Delli Carpini and Keeter 1996: chapter 2). Previous studies tend to be 
consistent in understanding political knowledge as a unidimensional concept that goes from low to high political knowledge. For this reason the usual measurement consists in a cumulative scale (see Delli Carpini and Keeter 1993; Mondak and Anderson 2004; Vettehen et al. 2004). For the sake of comparison between the two countries, in this case Mokken scale analysis (Mokken 1971) was applied to respondents' answers to construct a scale of political knowledge and to test its one-dimensional character and reliability. ${ }^{4}$ Our dependent variable is composed of the items that meet the criteria of such a scale in each of the two countries: 16 for the Finnish case (Cronbach's alpha: 0.83; Lowevinger's H: 0.41) and 13 in the case of Spain (Cronbach's alpha: 0.80; Lowevinger's H: 0.40). ${ }^{5}$ These items are marked with an asterisk in Tables A1 and A2 of the online appendix, which list all the items included in the questionnaires for each country. The scale counts the number of correct answers given by each respondent, and ranges from 0 to 100 , after rescaling. Overall levels of political knowledge, or gaps between men and women, cannot be compared directly between the two countries as the scales are formed by different items. However, our measurement ensures the reliable and valid measurement of political knowledge in each country and allows for the comparison of groups within each country. ${ }^{6}$

Family and job-related statuses or adult roles are our main independent variables. We selected indicators to account for the status of an individual in relation to three situations: (1) living with a partner: an individual that lives with their partner ${ }^{7}$ is coded 1 , whereas an individual is coded 0 if they still live with parents or alone; (2) entering the labour market: coded 1 if an individual is in paid employment at the time of data collection, and 0 if an individual is not in paid employment; and (3) having children: an individual is coded 1 if they had at least one child and otherwise 0 (see Table A7 in the online appendix for a description of the variables).

To control for the timing of transition events we include in all the estimations the respondents' highest level of education achieved and age. Previous studies have shown that the link between each adult role and political engagement varies according to the moment the event took place. For example, individuals who start a family at a very early stage of life tend to present lower levels of turnout, as compared to individuals who choose family life later in their life courses (Pacheco and Plutzer 2007). Early parenthood tends to result in early marriage and dropping out of the educational system. In turn, this implies low educational attainment and low income, and therefore low levels of involvement in politics.

We account also for the fact that socialisation during childhood and adolescence is related to levels of political engagement in adulthood. It is 
more likely that girls will get involved in politics if they learn about it at home than if family members never discuss politics (Jennings and Niemi 1974, 1981). Given the important role of the family in transmitting political interest (Jennings and Stoker 2009; Neundorf et al. 2013), and the fact that political socialisation precedes the acquisition of adult roles, we include a variable that captures the reported frequency of political discussions at home during respondents' childhood. ${ }^{8} \mathrm{~A}$ dichotomous indicator takes the value of 1 for respondents who grew up in a politicised family, and 0 for other respondents.

\section{Findings}

Our theoretical expectations are based on scattered evidence in previous studies that the gender gap in political knowledge, while irrelevant among adolescents and young adults, becomes evident as people adopt adult roles. We therefore start by exploring whether there is an increase in the gender gap in political knowledge from youth to adulthood in Finland and Spain. For this purpose, we have estimated a linear regression equation that incorporates as independent variables: education, age, age squared $^{9}$ and whether the respondent grew up in a politicised family. To measure gender differences across age, we specified an interaction term between sex and age squared. Table A8 in the online appendix summarises the results, while Figure 2 shows the predicted values of political knowledge across age groups in Finland and Spain. Findings show that the gender gap in political knowledge is relatively small until the age of 21 in both Spain and Finland (less than five percentage points of difference between men and women). From that age on the gap increases significantly until it doubles. The sole difference between the two countries is that the gap increases marginally quicker in Finland, at age 40 the difference between men and women is 8.5 points, while in Spain that same difference is reached at age 50 (see Figure 2).

As we have confirmed that the gender gap in political knowledge is wider among adults than among young people in both countries, we now test our hypotheses about the association between adult roles and levels of political knowledge. The analysis is limited to respondents aged 18 to 44 , in order to avoid comparing individuals whose entrance into the labour market, partnership or parenthood is relatively new with individuals who have experienced any of these three adult statuses long ago. ${ }^{10}$ To explore the relationship between the three adult statuses, gender and political knowledge, we estimate a linear regression equation that includes levels of education, age and growing up in a politicised family as control variables. ${ }^{11}$ We further investigate whether adult roles affect men's and 

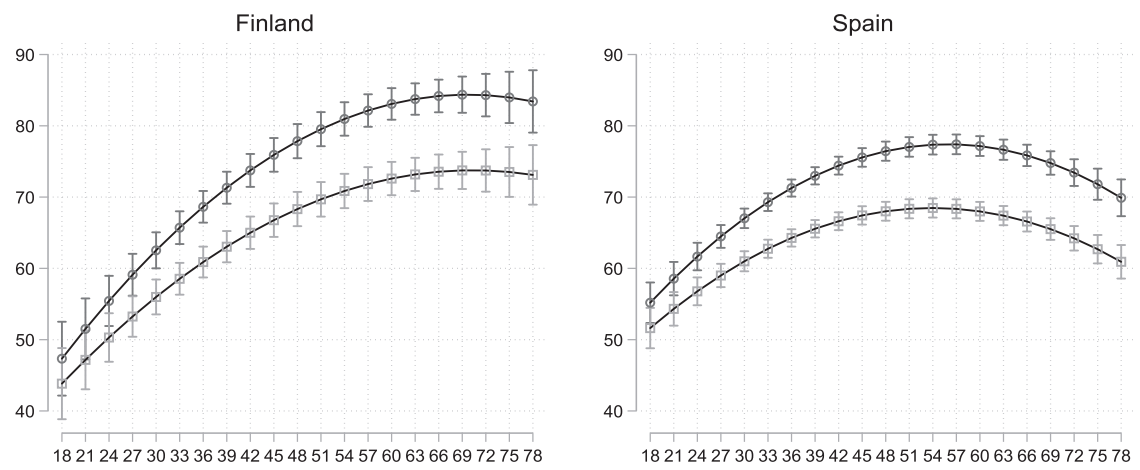

$\bullet-$ Men $\quad-\because-$ Women

Figure 2. Predicted political knowledge across age groups by sex: Finland and Spain. Source: Our elaboration on Table A8. Equations for Finland and Spain respectively. Error bars represent $95 \% \mathrm{Cl}$.

women's levels of political knowledge differently by specifying an interactive term between gender (female) and each of the adult statuses separately (see Models $2-5$ in Table 2 for Finland, and in Table 3 for Spain). Figure 3 illustrates the results with the marginal effects for men and women in each situation and in both countries.

Tables 2 and 3 (Model 1, column 2) suggest that each of the adult roles has a different impact on levels of political knowledge (although cohabitation and paid employment did not turn out to be statistically different from zero in Finland). Endorsing previous studies, sharing everyday life with a partner seems to be associated with an increase in resources and consequently higher levels of knowledge, something that is confirmed both for the Finnish and the Spanish cases. In contrast, having a child is negatively related to political knowledge, which indicates that this event is accompanied by a drop in leisure time, networks and/or attention paid to politics. Again, this finding is consistent with previous research and for both case studies. Being in paid employment, however, shows different results for Finland and Spain. While it is positively related to levels of political knowledge in Spain, the coefficient is negative (although not significant) in Finland. But are these relationships the same for women and for men? And do they vary across contexts? To simplify the interpretation of the results, the marginal effects of each situation on the political knowledge of men and women are presented in Figure 3.

Figure 3 shows how adult roles contribute to the gender differences in political knowledge, and how these vary across contexts. ${ }^{12}$ Firstly, we can see small gender differences in levels of political knowledge among individuals who are not in paid employment, in cohabitation or who have no children. However, while these small differences are significant in Spain, 
Table 2. Adult roles and political knowledge for men and women in Finland.

\begin{tabular}{lcccc}
\hline & Model 1 & Model 2 & Model 3 & Model 4 \\
\hline Education & $4.703^{* * *}$ & $4.747^{* * *}$ & $4.698^{* * *}$ & $4.653^{* * *}$ \\
& $(0.501)$ & $(0.500)$ & $(0.501)$ & $(0.502)$ \\
Age & $1.025^{* * *}$ & $1.038^{* * *}$ & $1.037^{* * *}$ & $1.024^{* * *}$ \\
& $(0.157)$ & $(0.157)$ & $(0.158)$ & $(0.157)$ \\
Female & $-6.740^{* * *}$ & -2.261 & -4.743 & -4.356 \\
& $(2.014)$ & $(3.219)$ & $(3.184)$ & $(2.739)$ \\
Politicized family & $3.522^{*}$ & $3.496^{*}$ & $3.541^{*}$ & $3.459^{*}$ \\
Lives with partner & $(2.048)$ & $(2.043)$ & $(2.049)$ & $(2.047)$ \\
& 2.756 & $6.451^{* *}$ & 2.433 & 2.734 \\
In paid employment & $(2.464)$ & $(3.216)$ & $(2.497)$ & $(2.462)$ \\
& -1.159 & -1.684 & 0.610 & -1.212 \\
Has a child & $(2.188)$ & $(2.202)$ & $(3.092)$ & $(2.187)$ \\
& $-5.456^{* *}$ & $-5.391^{* *}$ & $-5.390^{* *}$ & -2.669 \\
Female \# partner & $(2.353)$ & $(2.347)$ & $(2.355)$ & $(3.201)$ \\
& & $-7.220^{*}$ & & \\
Female \# paid employment & & $(4.054)$ & & \\
& & & -3.273 & \\
Female \# child & & & $(4.040)$ & -5.128 \\
& & & & $(3.998)$ \\
Constant & $12.84^{* * *}$ & $10.38^{* *}$ & $11.55^{* *}$ & $12.17^{* *}$ \\
& $(4.812)$ & $(4.995)$ & $(5.073)$ & $(4.837)$ \\
Observations & & & & \\
R-squared & 428 & 428 & 428 & 428 \\
\hline
\end{tabular}

OLS coefficients. Standard errors in parentheses.

${ }^{* * * *} p<0.01 i^{* *} p<0.05 ;{ }^{*} p<0.1$.

we find that Finnish male's and female's knowledge about politics is almost identical before being workers, spouses or parents. Secondly, the gender gap in knowledge is greater in both Finland and Spain for the group of respondents who have completed any of these three adult statuses, as compared to the jobless, the single and the childless. Female workers, spouses and mothers know systematically less about politics than men in the same situation in Finland and Spain (confirming H1 to H3: adult roles imply a more positive correlation - or less negative - with political knowledge for men than for women). This finding is in contradiction with $\mathrm{H} 4$ that hypothesised differences between Finland and Spain. A closer look at the results reveals that, except for cohabitation, the association of adult roles with women and men's levels of political knowledge differs across the two contexts.

In Spain, being in paid employment is positively related to levels of political knowledge both for women and for men. It is, however, men who benefit most from being employed. Predicted values of being employed increase by three points for men (70 to 73), but only by one point for women. As a consequence, the gender gap in political knowledge is higher among the workers than among the non-workers, as this status benefits mainly men. The gender gap in knowledge is also bigger among the workers than among non-workers in Finland but neither 
Table 3. Adult roles and political knowledge for men and women in Spain.

\begin{tabular}{|c|c|c|c|c|}
\hline & Model 1 & Model 2 & Model 3 & Model 4 \\
\hline Education & $\begin{array}{c}4.956^{* * *} \\
(0.267)\end{array}$ & $\begin{array}{c}4.942 * * * \\
(0.267)\end{array}$ & $\begin{array}{c}4.955 * * * \\
(0.267)\end{array}$ & $\begin{array}{c}4.936 * * * \\
(0.267)\end{array}$ \\
\hline Age & $\begin{array}{c}0.614 * * * \\
(0.0713)\end{array}$ & $\begin{array}{c}0.620^{* * *} * \\
(0.0712)\end{array}$ & $\begin{array}{c}0.614 * * * \\
(0.0713)\end{array}$ & $\begin{array}{c}0.622 * * * \\
(0.0713)\end{array}$ \\
\hline Female & $\begin{array}{c}-6.254^{* * *} \\
(0.879)\end{array}$ & $\begin{array}{c}-4.195^{* * *} \\
(1.316)\end{array}$ & $\begin{array}{c}-5.790 * * * \\
(1.311)\end{array}$ & $\begin{array}{c}-4.666^{* * *} \\
(1.163)\end{array}$ \\
\hline Politicised family & $\begin{array}{c}6.262 * * * \\
(0.922)\end{array}$ & $\begin{array}{c}6.165^{* * *} \\
(0.923)\end{array}$ & $\begin{array}{c}6.253 * * * \\
(0.923)\end{array}$ & $\begin{array}{c}6.212^{* * *} \\
(0.922)\end{array}$ \\
\hline Lives with partner & $\begin{array}{l}1.865^{*} \\
(1.109)\end{array}$ & $\begin{array}{c}3.707^{* * * *} \\
(1.413)\end{array}$ & $\begin{array}{l}1.857^{*} \\
(1.109)\end{array}$ & $\begin{array}{c}1.600 \\
(1.115)\end{array}$ \\
\hline In paid employment & $\begin{array}{c}2.772^{* * *} \\
(0.918)\end{array}$ & $\begin{array}{c}2.700^{* * * *} \\
(0.918)\end{array}$ & $\begin{array}{c}3.184^{* *} \\
(1.260)\end{array}$ & $\begin{array}{c}2.695^{* * *} \\
(0.918)\end{array}$ \\
\hline Has a child & $\begin{array}{c}-2.581^{* *} \\
(1.146)\end{array}$ & $\begin{array}{c}-2.805^{* *} \\
(1.150)\end{array}$ & $\begin{array}{c}-2.602^{* *} \\
(1.147)\end{array}$ & $\begin{array}{l}-0.650 \\
(1.473)\end{array}$ \\
\hline Female \# partner & & $\begin{array}{c}-3.658^{* *} \\
(1.741)\end{array}$ & & \\
\hline Female \# employment & & & $\begin{array}{l}-0.828 \\
(1.736)\end{array}$ & \\
\hline Female \# child & & & & $\begin{array}{c}-3.673^{* *} \\
(1.764)\end{array}$ \\
\hline Constant & $\begin{array}{c}29.26 * * * \\
(2.212)\end{array}$ & $\begin{array}{c}28.31^{* * * *} \\
(2.256)\end{array}$ & $\begin{array}{c}29.04 * * * \\
(2.262)\end{array}$ & $\begin{array}{c}28.56 * * * \\
(2.236)\end{array}$ \\
\hline Observations & 1682 & 1682 & 1682 & 1682 \\
\hline R-squared & 0.313 & 0.315 & 0.313 & 0.315 \\
\hline
\end{tabular}

OLS coefficients. Standard errors in parentheses. $p<0.01 ;{ }^{* *} p<0.05 ;{ }^{*} p<0.1$.

(especially) women nor men seem to 'take advantage' of the fact of being employed. Quite the contrary, working seems to depress levels of political knowledge in general, but the penalty is bigger for women than for men. Having a child appears to be the most challenging status for keeping informed about politics. Indeed, having a child is negatively related to levels of knowledge for both women and men in Finland and Spain. But it is in Finland where the association is stronger for the two sexes: being a parent reduces the predicted values of knowledge by eight points for women and three points for men (as compared to four points for women and negligible effects for men in Spain). The only event that is similar in Finland and Spain for the two sexes is cohabitation. The middle section of Figure 3 shows that cohabiting does not imply higher levels of political knowledge for women, while living with a partner results in higher levels of political knowledge for men, both in Finland and Spain (six and four points respectively). Given our findings, H4 needs further nuancing to fully uncover contextual differences; we seek greater refinement in the final discussion.

\section{Conclusion and discussion}

Despite the progress made in the last few decades on gender equality, women still appear to know less than men about politics in most Western democracies. The common finding that the gender gap is greater among 
Finland

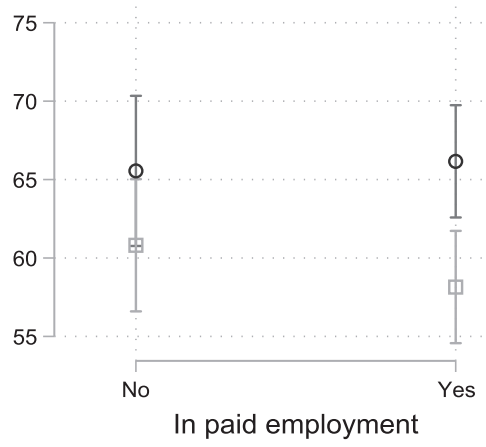

Finland

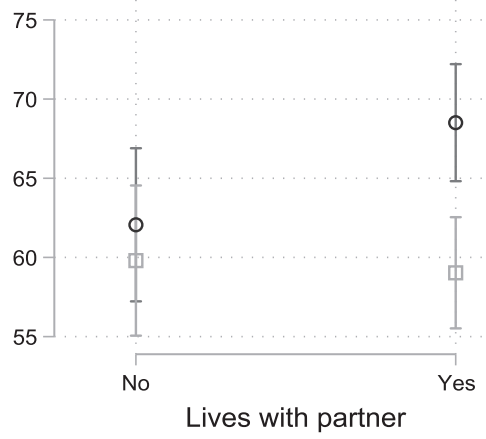

Finland

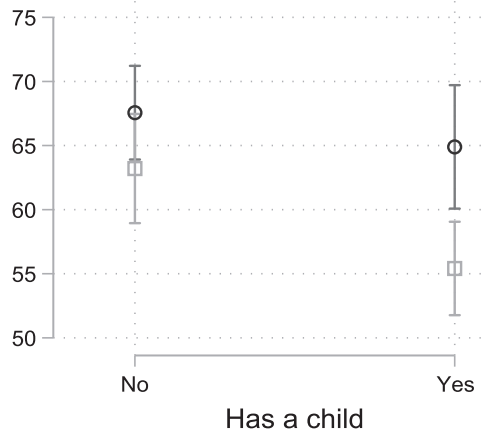

O Men
Spain

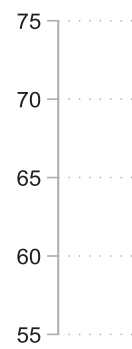

No

In paid employment

Spain

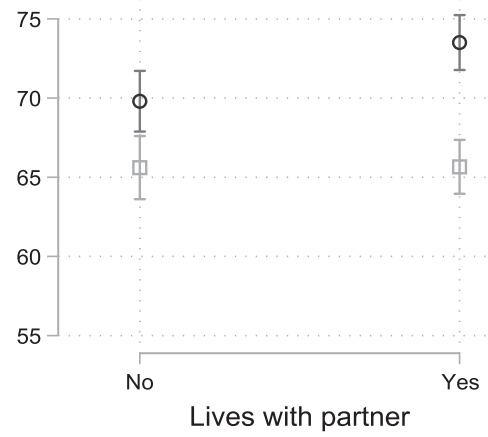

Spain

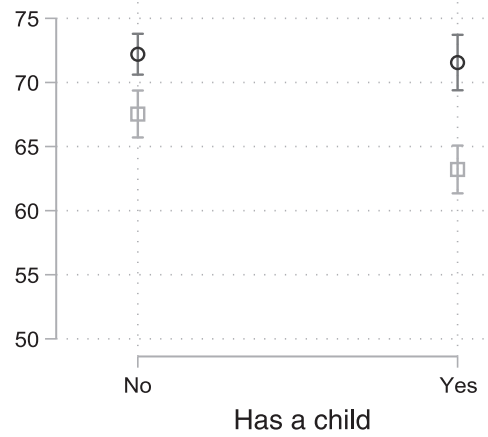

Women

Figure 3. Predicted political knowledge and adult roles for men and women.

Note: Error bars represent $95 \% \mathrm{Cl}$. Predictions are calculated on the basis of the estimates provided in Tables 2 and 3.

adults than among young people has been understudied by political scientists. Understanding this finding might help to address one of the most immediate (and persistent across contexts) causes of gender political 
inequality. This article is a first attempt to explain why being an adult results in a gender gap in political knowledge. Comparing levels of political knowledge after the acquisition of adult roles in two such dissimilar cases as Finland and Spain provides insights into the explanations behind the persistence of the gender gap in political knowledge. It appears that women are systematically disadvantaged (as compared to men) as they become workers, spouses and/or mothers. In general, adult roles provide more opportunities for men to gain political knowledge than women. Notably, this finding is a constant for our two case studies, which apparently contradicts $\mathrm{H} 4$ and puts into question the efficacy of gender equality policies to increase women's participation in the political sphere. Our findings nonetheless call for a nuancing of our hypothesis, as they reveal interesting differences between the Finnish and the Spanish cases.

To start with, the gender gap develops quicker in Finland than in Spain. Differences between jobless, single and childless women and men (that is, before they have acquired any of these three adult roles) in the two contexts are also meaningful. While in Spain women know significantly less than men even when none of the three adult statuses has been acquired, differences between women and men are of a small magnitude and barely significant in Finland. Finally, whereas Spanish men are never penalised (and in fact are mostly advantaged) by being in paid employment, cohabiting or having kids, Finnish men appear to share with Finnish women the costs of being in paid employment and having kids. The persistence of the gender gap in the two case studies, despite the fact that adult roles relate differently with women and men's knowledge, suggests that both Finnish and Spanish women might still bear the greatest burden of family responsibilities (cohabitation is surely the most telling case), which would always results in them gaining less political knowledge than men.

Substantially, our findings suggest that gender equality policies (and structural equality) are effective in levelling women and men's political knowledge, as they tend to balance the costs of adulthood. Structural equality alone might not yet be enough to entirely avoid the gender gap in political knowledge. 'Everyday practices' are indeed as important as structural equality to ensure gender equality. In the words of Rubery (2013: 27):

Gender relations have probably experienced more sustained change than other institutional domains, resulting in many countries in an increasing mismatch between the form of gender relations as practised by citizens and the form of gender relations embedded in welfare state and labour markets.

The evidence shown here is based on two cross-sectional analyses, so this article is limited in that we cannot assess the net effect of transitions and events at the individual level. We believe future research ought to address this shortcoming and we campaign so that political behaviour 
researchers consider the importance of including political knowledge measures in longitudinal surveys. This type of evidence, until now unavailable, would allow the specific mechanisms to be identified by which life events push or inhibit the development of political knowledge, which we have speculated relate to the availability of time, the exposure to mobilisation agencies and the amount and diversity of social networks.

\section{Notes}

1. For the latest evidence finding no gender differences in political knowledge among young people aged 18-24 in the US see Campbell and Niemi (2016). Some studies find that there are already differences in levels of political knowledge at an early age (Abendschön and Tausenpfund 2017; Greenstein 1965; van Deth et al. 2011). However, most recent work shows that the size of the gender gap depends on the type of knowledge measured (Ferrín et al. 2015; Simon 2017).

2. The latest data on the percentage of part-time employment of adults by sex, age group, number of children and age of youngest child is available at Eurostat (lfst_hhptechi). The data were consulted on 27 March 2017. A summary is available at: http://ec.europa.eu/eurostat/documents/2995521/ 7202372/3-07032016-AP-EN.pdf/

3. The population aged 18-44 was over-represented in the sample.

4. The so-called Mokken scale analysis is a technique often used to construct scales of political knowledge, see for example Vettehen et al. (2004) and Munzert and Selb (2015). As we are interested in gender differences, we previously corroborated that the same items conform to a unidimensional construct of political knowledge for men and women separately.

5. No other scales resulted in the inclusion of all items. Three of the items in Spain were excluded from the analysis as they were designed as experimental conditions for an unrelated topic. Details on the scale and Mokken scale coefficients for each item in the scale are available in Tables A3 and A4 in the online appendix. Preliminary tests explored the possibility of building four content-based scales according to the type of political knowledge the items relate to: classic, democracy, policies, economic questions (see last column of Tables A1 and A2 in the online appendix for each item). Only the first type, classic knowledge, conformed to a unidimensional scale. As a robustness test, the analyses presented below were replicated with this additional dependent variable and are available in Tables A5 and A6 in the online appendix. The results confirm the main findings and also previous research showing that the size of the gender gap in knowledge is larger when including only knowledge items about elections, parties and candidates (Ferrín et al. 2018). In addition, as a robustness check, we have replicated the analyses with all the items included in the two surveys (29 in Finland and 30 in Spain) with identical results.

6. Identical items, even if they were available, would not necessarily improve the comparison of levels of political knowledge across countries.

7. All individuals who live with their partner are coded 1, independent of whether they also live with their parents. This is a very small number of 
respondents for the Spanish case (33 individuals). Information is not available for Finland.

8. The exact wording of the question for Finland is 'How much knowledge would you say you have gained about social and political matters: at home?', originally measured on a five-point scale from 5 'a lot' to 1 'none'. For Spain: 'As far as you remember, how frequently did you discuss politics at home when you were a child or adolescent?', measured on a scale from 4 'Very frequently' to 0 'Never'. Although the wording of the questions differs, they are meant to capture the same information. In any case, all the results presented here are robust if this control variable is excluded. The variables were dichotomised to compare highly politicised families (values 5 and 4 in Finland, frequently or very frequently in Spain) to less politicised families.

9. Previous tests showed a curvilinear relation between age and knowledge confirming previous research (see, for instance, Strate et al. 1989: 451).

10. The limit of 44 years is based on the average age range for the three transition events. The event that takes place later in both countries is childbirth: in 2012 the women's average age at first birth was 29 years in Finland and 31 years in Spain (on average children are 15 years old in Finland and 13 years old in Spain when their parents are 44). Since age is limited to 44 in the following estimations there is no need to control for age squared to address the curvilinear relationship described above. As a robustness check, we have however replicated the analyses with all respondents in the sample (see Table A9 and A10 in the online appendix), and the results are confirmed.

11. Other standard controls such as political interest or media attention are not included in the equation as they might entail a problem of endogeneity. For example, the acquisition of adult roles could result in a decrease in the time available for media consumption for the same reason as losing interest in politics, thus depressing political knowledge. However, the replication of the equations presented here with these additional control variables shows that the results presented in the most parsimonious models above are robust (see Tables A11 and A12 in the online appendix).

12. As a robustness check, we have replicated the same analysis with data from the European Social Survey 2002 for Spain and Finland. Even though there is a significant limitation in the number of the items available to measure political knowledge (five) and the risk of error measurement in our dependent variable is higher, results are consistent with our findings. The similarity of the findings in the ESS makes us confident about the results presented here.

\section{Acknowledgements}

We thank Anand Menon, Klaus Goetz and the anonymous reviewers for their generous and valuable comments and suggestions.

\section{Funding}

This work was supported by the Spanish Ministry of Economy and Competitiveness (under grants CSO2016-75090-R and CSO2012-32009) and the Centro de Investigaciones Sociológicas (CIS). 


\section{Notes on contributors}

Mónica Ferrín is Intalent and Ramón y Cajal Researcher at the University of Coruña. Her research focuses on public opinion, political participation, democracy and gender. Amongst others, she has published in Politics \& Gender and the Journal of Common Market Studies. She has also co-edited the collective volume How Europeans View and Evaluate Democracy (Oxford University Press). [monica.ferrin@carloalberto.org]

Marta Fraile is Senior Research Fellow at the Consejo Superior de Investigaciones Científicas (CSIC) (Instituto de Políticas y Bienes PúblicosMadrid). She has held teaching and research positions in different universities. Her research spans the fields of public opinion, gender and politics, and political participation. She has published in journals such as British Journal of Political Science, European Journal of Political Science, European Union Politics and Political Research Quarterly. [marta.fraile@eui.eu]

Gema García-Albacete is Assistant Professor at the Department of Social Sciences, Universidad Carlos III de Madrid. Her research relates to citizens' inequalities in political interest, knowledge and political participation across Western democracies. Her current work focuses on two main topics: political engagement among young people and persistent gender gaps in political attitudes and behaviours. Her work has been published in Politics \& Gender, International Journal of Public Opinion Research, Information, Communication and Society and American Behavioral Scientist, among others. [gemgarci@clio.uc3m.es]

\section{ORCID}

Gema M. García-Albacete (D) http://orcid.org/0000-0002-2457-5699

\section{References}

Abendschön, Simone, and Markus Tausendpfund (2017). 'Political Knowledge of Children and the Role of Sociostructural Factors', American Behavioral Scientist, 61:2, 204-21.

Banducci, Susan, Laurel Elder, Steven Greene, and Daniel Stevens (2016). 'Parenthood and the Polarisation of Political Attitudes in Europe', European Journal of Political Research, 55:4, 745-66.

Batalova, Jeanne A., and Philip N. Cohen (2002). 'Premarital Cohabitation and Housework: Couples in Cross-National Perspective', Journal of Marriage and Family, 64:3, 743-55.

Baxter, Janeen, Belinda Hewitt, and Michele Haynes (2008). 'Life Course Transitions and Housework: Marriage, Parenthood, and Time on Housework', Journal of Marriage and Family, 70:2, 259-72.

Baxter, Janeen, Sandra Buchler, Francisco Perales, and Mark Western (2015). 'A Life-Changing Event: First Births and Men's and Women's Attitudes to Mothering and Gender Divisions of Labor', Social Forces, 93:3, 989-1014.

Buchmann, Marlis C., and Irene Kriesi (2011). 'Transition to Adulthood in Europe', Annual Review of Sociology, 37:1, 481-503. 
Burns, Nancy, Kay Lehman Schlozman, and Sidney Verba (2001). The Private Roots of Public Action. Cambridge, MA: Harvard University Press.

Campbell, David D., and Richard Niemi (2016). 'Testing Civics: State-Level Civic Education Requirements and Political Knowledge', American Political Science Review, 110:3, 495-511.

Dassonneville, Ruth, and Ian McAllister (2018). 'Gender, Political Knowledge, and Descriptive Representation: The Impact of Long-Term Socialization', American Journal of Political Science, 62:2, 249-65.

Delli Carpini, Michael, and Scott Keeter (1993). 'Measuring Political Knowledge: Putting First Things First', American Journal of Political Science, 37:4, 1179-206.

Delli Carpini, Michael, and Scott Keeter (1996). What Americans Know About Politics and Why It Matters. New Haven: Yale University Press.

Delli Carpini, Michael, and Scott Keeter (2005). 'Gender and Political Knowledge', in Sue Tolleson-Rinehart and Jyl L. Josephson (eds), Women, Men and the Political Process. New York: M.E. Sharpe, 21-43.

Dolan, Kathleen (2011). 'Do Women and Men Know Different Things? Measuring Gender Differences in Political Knowledge', The Journal of Politics, 73:1, 97-107.

Elo, Kimmo, and Lauri Rapeli (2014). Knowledge of Politics and Society 2008 [Dataset]. Finnish Social Science Data Archive. http://urn.fi/urn:nbn:fi:fsd:TFSD2499.

Elo, Kimmo, and Lauri Rapeli (2010). 'Determinants of Political Knowledge: The Effects of the Media on Knowledge and Information', Journal of Elections, Public Opinion and Parties, 20:1, 133-46.

Esping-Andersen, Gøsta (1990). The Three Worlds of Welfare Capitalism. Hoboken, NJ: John Wiley \& Sons.

Ferrera, Maurizio (1996). 'The 'Southern Model' of Welfare in Social Europe', Journal of European Social Policy, 6:1, 17-37.

Ferrín, Monica, Fraile Marta, and Gema García-Albacete (2017). 'The Gender Gap in Political Knowledge: Is It All About Guessing? An Experimental Approach', The International Journal of Public Opinion Research, 29:1, 111-32

Ferrín, Mónica, Marta Fraile, and Martiño Rubal (2015). 'Young and Gapped? Studying Civic Knowledge of Girls and Boys in Europe', Political Research Quarterly, 68:1, 63-76

Ferrín, Monica, Marta Fraile, and Gema García-Albacete (2018). 'Is It Simply Gender? Content, Format, and Time in Political Knowledge Measures', Politics \& Gender, 14:2, 162-85

Fortin-Rittbergger, Jessica (2016). 'Cross-National Gender Gaps in Political Knowledge: How Much Is Due to Context?' Political Research Quarterly, 69:3, 391-402.

Fraile, Marta (2014). 'Do Women Know Less About Politics Than Men? The Gender Gap in Political Knowledge in Europe', Social Politics, 21:2, 261-89

Fraile, Marta, and Raúl Gomez (2017). 'Why Does Alejandro Know More about Politics than Catalina? Explaining the Latin American Gender Gap in Political Knowledge', British Journal of Political Science, 47:1, 91-112.

Gallagher, Sally K., and Naomi Gerstel (2001). 'Connections and Constraints: The Effects of Children on Caregiving', Journal of Marriage and Family 63:1, 265-75. 
García-Albacete, Gema (2014). Young People's Political Participation in Western Europe: Continuity or Generational Change? Basingstoke: Palgrave Macmillan

Gauthier, Anne H., and Frank F. Furstenberg (2002). 'The Transition to Adulthood: A Time Use Perspective', The Annals of the American Academy of Political and Social Science, 580:1, 153-71.

Goetzmann, Anke (2017). 'Elementary School Children's Political Knowledge', American Behavioral Scientist, 61:2, 238-53

Greenstein, Fred (1965). Children and Politics. New Haven: Yale University Press. Hahn, Carole (1998). Becoming Political: Comparative Perspectives on Citizenship Education. Albany, NY: State University of New York Press.

Hilson, Mary (2008). The Nordic Model: Scandinavia since 1945. London: Reaktion Books.

ILO (2015). Women in Non-standard Employment. Geneva: International Labour Office (ILO).

Jennings, M. Kent (1996). 'Political Knowledge over Time and Across Generations', Public Opinion Quarterly, 60:2, 228-52.

Jennings, M. Kent, and Richard G. Niemi (1974). The Political Character of Adolescence: The Influence of Families and Schools. Denmark: Books on Demand.

Jennings, M. Kent, and Richard G. Niemi (1981). Generations and Politics: A Panel Study of Young Adults and Their Parents. Princeton, NJ: Princeton University Press.

Jennings, M. Kent, and Laura Stoker (2009). 'Politics Across Generations. Family Transmission Re-examined', Journal of Politics, 71:3, 782-99

Knudsen, Knud, and Kari K. Waerness (2008). 'National Context and Spouses' Housework in 34 Countries', European Sociological Review, 24:1, 97-113.

Kostelka, Filip, André Blais, and Elisabeth Gidengil (2019). 'Has the Gender Gap in Voter Turnout Really Disappeared?’ West European Politics, 42:3, 437-63.

Lane, Robert E. (1959). Political Life: Why People Get Involved in Politics. Glencoe: The Free Press.

Mayer, Karl Ulrich (2001). 'The Paradox of Global Social Change and National Path Dependencies: Life Course Patterns in Advanced Societies', in A. Woodward and Martin Kohli (eds), Inclusions and Exclusions in European Societies. New York: Routledge.

Mellens, Martin (1999). 'Uniformity and Diversity Defined', in Joop De Beer and Leo Van Wissen (eds), Europe: One Continent, Different Worlds. European Studies of Population 7. The Netherlands: Springer, 33-44.

Mokken, Robert J. (1971). A Theory and Procedure of Scale Analysis with Applications to Political Research. The Hague: Mouton.

Mondak, Jeffery J., and Mary R. Anderson (2004). 'The Knowledge Gap: A Reexamination of Gender-Based Differences in Political Knowledge', The Journal of Politics, 66:2, 492-512.

Munch, Allison, J. Miller McPherson, and Lynn Smith-Lovin (1997). 'Gender, Children, and Social Contact: The Effects of Childrearing for Men and Women', American Sociological Review, 62:4, 509-20.

Munzert, Simon, and Peter Selb (2015). 'Measuring Political Knowledge in WebBased Surveys: An Experimental Validation of Visual versus Verbal Instruments', Social Science Computer Review, 35:2, 167-83 
Neundorf, Anja, Kaat Smets, and Gema García-Albacete (2013). 'Homemade Citizens: The Development of Political Interest During Adolescence and Young Adulthood', Acta Politica, 48:2, 92-116.

Ondercin, Heather L., and Daniel Jones-White (2011). 'Gender Jeopardy: What is the Impact of Gender Differences in Political Knowledge on Political Participation?' Social Science Quarterly, 92:3, 675-94.

Pacheco, Julianna S., and Eric Plutzer (2007). 'Stay in School, Don't Become a Parent. Teen Life Transitions and Cumulative Disadvantages for Voter Turnout', American Politics Research, 35:1, 32-56.

Quaranta, Mario (2016). 'Leaving Home, Finding a Partner and Having Kids: Gender Differences in Political Participation across the Life Course in Italy', Acta Politica, 51:33, 372-97.

Quaranta, Mario, and Giulia M. Dotti-Sani (2018). 'Left Behind? Gender Gaps in Political Engagement over the Life Course in 27 European Countries', Social Politics, 25:2, 254-86

Rubery, Jill (2013). 'From 'Women and Recession' to 'Women and Austerity': A Framework for Analysis', in Maria Kramessini and Jill Rubery (eds), Women and Austerity: The Economic Crisis and the Future for Gender Equality. Abingdon: Routledge.

Sapiro, Virginia (1982). 'Private Costs of Public Commitments or Public Costs of Private Commitments? Family Roles versus Political Ambition', American Journal of Political Science, 26:2, 265-79.

Sayer, Liana C. (2005). 'Gender, Time and Inequality: Trends in Women's and Men's Paid Work, Unpaid Work and Free Time', Social Forces, 84:1, 285-303.

Schlozman, Kay Lehman, Nancy Burns, and Sidney Verba (1994). 'Gender and the Pathways to Participation: The Role of Resources', The Journal of Politics $56: 4,963-90$.

Schlozman, Kay Lehman, Nancy Burns, and Sidney Verba (1999). 'What Happened at Work Today? A Multistage Model of Gender, Employment, and Political Participation', The Journal of Politics, 61:1, 29-53.

Shanahan, Michael J. (2000). 'Pathways to Adulthood in Changing Societies: Variability and Mechanisms in Life Course Perspective', Annual Review of Sociology, 26:1, 667-92.

Simon, Alice (2017). 'How Can We Explain the Gender Gap in Children's Political Knowledge?' American Behavioral Scientist, 61:2, 222-37.

Stoker, Laura, and Kent M. Jennings (1995). 'Life-Cycle Transitions and Political Participation: The Case of Marriage', American Political Science Review, 89:2, 421-33.

Stolle, Dietlind, and Michele Micheletti (2013). Political Consumerism: Global Responsibility in Action. Cambridge: Cambridge University Press.

Stolle, Dietlind, and Elisabeth Gidengil (2010). 'What Do Women Really Know? A Gendered Analysis of Varieties of Political Knowledge', Perspectives on Politics, 8:1, 93-109.

Strate, John M., Charles J. Parrish, Charles D. Elder, and Coit Ford (1989). 'Life Span Civic Development and Voting Participation', The American Political Science Review, 83:2, 443-64.

Torney-Purta, Judith, Rainer Lehmann, Hans Oswald, and Wolfram Schulz (2001). 'Citizenship and Education in Twenty-Eight Countries: Civic Knowledge and Engagement at Age Fourteen', Available at http://works. bepress.com/wolfram_schulz/8. Last consulted November 2018. 
van Deth, Jan W., Simone Abendschön, and Meike Vollmar (2011). 'Children and Politics: An Empirical Reassessment of Early Political Socialization', Political Psychology, 32, 147-74

Verba, Sidney, Kay Lehman Schlozman, and Henry E. Brady (1995). Voice and Equality: Civic Voluntarism in American Politics. Cambridge, MA: Harvard University Press.

Vettehen, Hendriks P., C. P. Hagemann, and L. B. van Snippenburg (2004). 'Political Knowledge and Media Use in the Netherlands', European Sociological Review, 20:5, 415-24.

Voorpostel, Marieke, and Hilde Coffé (2010). 'Transitions in Partnership and Parental Status, Gender, and Political and Civic Participation', European Sociological Review, 28:1, 28-42.

Welch, Susan (1977). 'Women as Political Animals? A Test of Some Explanations for Male-Female Political Participation Differences', American Journal of Political Science, 21:4, 711-30. 